UDC 821.581.091:323.113(=581)

\title{
THE IMAGOLOGICAL APPROACH TO THE OVERSEAS CHINESE LITERATURE
}

\author{
T. Vechorynska \\ $\mathrm{PhD}$ (Philology) \\ Institute of Philology, Taras Shevchenko National University of Kyiv \\ 14, Taras Shevchenko Blvd., Kyiv, 01601, Ukraine \\ t.vechorynska@gmail.com \\ ORCID ID: 0000-0002-6942-4237 \\ O. Vorobei \\ PhD (Philology) \\ Institute of Philology, Taras Shevchenko National University of Kyiv \\ 14, Taras Shevchenko Blvd., Kyiv, 01601, Ukraine \\ oerjia@gmail.com \\ ORCID ID: 0000-0003-4956-8943
}

Overseas Chinese literature refers to literary works written in Chinese by the Chinese living outside of China. Rooted in the soil of Chinese culture, Overseas Chinese literature appears as a unique literary phenomenon widespread throughout the world and created amidst foreign cultures. Overseas Chinese writers find themselves under a double cultural background. In their writings, there are many literary representations of different cultures' meeting, collision, and merging. The paper suggests that the imagology method may answer the question of how Chinese diaspora members define themselves as Chinese to construct their own identities as opposed to everything else, they regard as non-Chinese. With the application of the methods of Western and Chinese Schools of Comparative Literature and their respective interpretations of global literary processes, comparative literary imagology is discussed against its theoretical and historical background and questions such highly disputable categories as 'Chineseness' and 'Chinese consciousness'. The article provides an imagological interpretation of the Self and the Other distinction in Oiled Paper Umbrella by Chinese-Filipino writer Pei Qiong. It is proposed to consider the intertext of a given national representation as a trope, and thus to study semantics and poetics of a transnational individual representation. The analysis of modern critical approaches to the Overseas Chinese literature shows that the vector of critical comprehension of this literary phenomenon is gradually shifting from the ethnic paradigm to the transnational, transcultural interpretation of a person's connection with the mother culture. The article investigates how the transcultural images are constructed in the literary imagination space and how they are represented in a literary text. The special emphasis is placed on the methods of comparative literary imagology that considers the intrinsic textual peculiarities beyond the extrinsic ethnocentric concepts. It is shown that transcultural images employed in the Chinese-Swedish writer Wan Zhi's The Woman in a Trench Coat cannot be narrowed down to mere contextualization of the Self-the Other dyad, which is considered as a point of profound cultural significance in the field of Overseas Chinese literature research.

Keywords: comparative literary imagology, Other, Overseas Chinese Literature, Self, transcultural identity

(C) 2021 T. Vechorynska and O. Vorobei; Published by the A. Yu. Krymskyi Institute of Oriental Studies, NAS of Ukraine on behalf of The World of the Orient. This is an Open Access article distributed under the terms of the Creative Commons Attribution License (https://creativecommons. org/licenses/by-nc/4.0/).

The World of the Orient, 2021, № 1 
An important issue of modern comparative studies in the age of globalization is associated with the East-West critical discourse. Despite the historically developed Eurocentricity of comparative literary criticism [Bernheimer 1995; Hutcheon 1996; Fusco 2006] this discipline is increasingly beginning to look closely at the East. Fusco calls East-West Comparative Literature a panacea and emphasizes that many topics related to the three pillars of modern comparative studies - East, West, and literature - today need a reassessment [Fusco 2006]. The Chinese, and more broadly the Eastern, component of the literary comparative studies discourse is also a focus of Chinese comparatists [Yue 2004; Zhang Y. 1998; Zhang L. 1994]. According to Yue Daiyun, the engagement of Chinese comparative literature will result in a diverse development and new renaissance of the discipline in the West [Yue 2004, 13]. Cao Shunqing puts forward the basic theoretical feature of the Chinese School of Comparative Literature: "if the French School is characterized by the influence study and the American school by the parallel study, the Chinese school then might be regarded as one typical of cross-cultural study" [Cao 2000, 44]. According to Cao Shunqing, the Chinese school of comparative literature will cross the different cultures between East and West and reconstruct the concept of World Literature by connecting Eastern and Western literature. A distinguished comparatist Ning Wang's view of the processes in the modern world is predominantly East-centered: "Globalization is no doubt a traveling process from the West to the East" [Ning 2004, 585]. Ning calls on his colleagues for active dialogue, the creation of the global comparative studies with a consideration of a huge Chinese potential that manifests itself not just in economy, but is more apparent in some other aspects of the cultural life and literary works: "The strong mechanism of Chinese culture is more and more affected. As comparatists, we cannot and should not stop such a process, but we could make full use of this opportunity to 'globalize' our discipline in an attempt to broaden its ever-shrinking domain and to make it a truly globalized research field" [Ning 2004, 597]. It is not about the application of the Western theory to Chinese literary texts - this procedure was assessed as the utopian project by David Palumbo-Liu back in 1992 [Palumbo-Liu 1992]. It is about comprehending and incorporating the great literary and cultural potential of China into the global discourse.

Overseas Chinese literature, being the object of this research, is a literary phenomenon that emerged after the reform and opening-up policy, and it is closely related to cultural exchanges between China and foreign countries. Overseas Chinese writers are located all over the world in different countries and cultures. This is a mobile community of groups or individuals, separated by time and space, each having complex and unique backgrounds. All that unites them is their Chinese-language writings. Rao Pengzi defines it as a special space of Chinese literature with cross-cultural characteristics [Rao 2011]. This special space is composed of both the essence of traditional Chinese culture and the metamorphoses resulting from dialogue with the Other.

Leung notes that from a scientific point of view, one should distinguish between Overseas Chinese-language literature (海外华文文学 haiwai huawen wenxue) and Overseas non-Chinese-language literature（海外非华文文学 haiwai fei huawen wenxue) [Leung 2006, 118]. Even though both types of literature are written outside of China by writers of Chinese origin, their reception by Chinese literary criticism is very different. The long history of Chinese emigration has resulted in that many Chinese, as well as their descendants, adopt other languages as a means of expression. The "bilingual poetics" employed in their writings receives close attention in the West. Compared to the rather active discussion of the Chinese-language literary world heritage [Lai 1993; Pan 1996; Gong 2000; Rao 2004; Tsu and Wang 2010], Chinese scholars exclude literary works written in others languages from the discourse and consider them mainly in the context of the relevant national literature. Chinese scholar Zhang Longhai explains this in imagological terms: China in the minds of Overseas Chinese writers is not the China that they have personally 
experienced, but rather vague impressions about China that they have obtained through news media, books, and stories of their parents [Cheung 2018, 150]. Thus, the representation of China employed in their writings is viewed as antithetical to real China. On the contrary, Overseas Chinese-language literature is praised due to the so-called "Chinese consciousness" (中国意识 zhongguo yishi), which indicates a certain level of kinship with China, when an emigrant, regardless of his identity, while abroad, seeks to create and express values and ideals in Chinese. This way, in Chinese literary criticism, the corpus of literary works of the Chinese diaspora, similar in its semantics and poetics, breaks up into separate discourses of "own" (Chinese-language) and "alien" (foreign-language).

The imagological approach to Overseas Chinese Literature is important for understanding the interaction of the Self and the Other as components of the representation of the Overseas Chinese cultural identity. The fundamental premises in asserting the Self are seen in the very linguistic definitions of the Chinese people living outside of China, formed at different historical stages. In imagological terms, we speak about an imageme, a concept introduced by Leerssen to denote a fixed cliché, consisting of two contrasting national qualities. An imageme is the term used to describe an image in all its implicit, compounded polarities [Beller and Leerssen 2007, 344]. An expanded definition of an imageme within the framework of literary imagology is proposed by Świderska: it is "[...] any element of a certain national culture or cultures which appear in the text" [Świderska 2013]. The integral system of imagemes in a literary text forms its "strange" (or "foreign") imagotheme, which can have ideological or utopian nature.

Most of the definitions - Chinese nationals residing abroad (华侨 huaqiao), a foreign citizen of Chinese origin (华裔 huayi) or overseas Chinese emigrant (海外华人 haiwai huaren) - are based on hua imageme, which invariably attribute the phenomenon of the diaspora, diverse in its essence, to the dominant image of the Chinese nation. On a broader scale, it refers to Sinocentrism - an ethnocentric belief that China is the political, cultural, and economic center of the world. This distinction between the Self and the Other was long ago articulated in China as "hua yi dichotomy" (华夷之辨 hua yi zhi bian), the concept that differentiated a culturally defined “China" (华 hua or 夏 xia) from cultural or ethnic outsiders or barbarians (夷 $y i$ ).

Western literary criticism, on the contrary, has coined the term "Chineseness" to address the unifying characteristics of the Chinese diaspora. The representation of the images of Chineseness "as trope" (in Leerssen's understanding) is associated with the discourse about Orientalism, implicitly present in Asian-American studies since the second half of the 20th century. Literary and cultural studies of recent years have noticeably problematized the category of Chineseness. Researchers have moved away from the established ethnocentric and essentialist interpretations, to highlight its moral, ethical, and aesthetic characteristics. The Eastern discourse about "Asian values" and "Cultural China" has modified the trends in cross-American studies. Ien Ang defines Chineseness as a discursive construct that has no fixed content but operates as an open and indeterminate signifier whose meaning is constantly renegotiated and rearticulated in different sections of the Chinese diaspora [Ang 2001,38]. There are plenty of studies concerned with the analysis of the "Chineseness" concept, be it its social, political, geographical, cultural, or racial aspects [Ong and Nonini 1997; Wu 1991; Chow 2000; Shu 2005].

Within the theoretical discourse on "Chineseness", Xiaomei Chen's Occidentalism [Chen 2002], has acquired special imagological importance since it enters into polemics with E. Said's Orientalism [Said 2003], proposing a new model of comparative literary and cultural studies, and a fundamentally new approach to the well-established interpretation of the Other by the West. Thus appears an image opposition of "Chinese Occidentalism" vs "Western Orientalism". Occidentalism as a counter-discourse is a part of the ideological reform in China in the 1980s, a special form of "self-appropriation" as opposed to Western "intellectual colonization" of the East. An American scholar of Chinese 
origin shows that Orientalism should not remain an orthodox theory, equally applicable to all countries in all historical periods, while continuing to view the East as any form of the Other, as antithetical to the dominant power of the West. At the turn of the century, China acquired a new status in the world, which allows it to view the West as the Other. However, the author emphasizes, this affirmation is not for the colonization of the West, but the proclamation of own cultural and symbolic capital [Chen 2002, 22].

Considering imagological aspects in the studies on émigré narratives, unlike repeatedly criticized ethnic and sociological aspects, supposes a more fluid and modulated approach to grasping the semantics and poetics of heteroimages and autoimages of the Chinese in the Overseas Chinese literary writings, and makes it possible to fully comprehend their artistic concept in representing the transnational individual. Scientific interest in literary imagology was already evident in the early studies of comparatists, describing its history and methods, as well the necessity to move away from ethno-sociological assumptions, to the analysis of literary material [Wellek 1963; Dyserinck 2003; Beller and Leerssen 2007]. In Imagology: The Cultural Construction and Literary Representation of National Character Leerssen suggests that in literary writings, "[i]mages do not reflect identities, but constitute possible identifications" and " $[t]$ he ultimate perspective of image studies is a theory of cultural or national stereotypes, not a theory of cultural and national identity" [Beller and Leerssen 2007, 27]. Imagology is thus concerned with the representations as textual strategies and as discourse and outlines a range of issues that cannot be ignored by researchers of the images of countries and peoples. If any national image is given as a special representation, the primary task of the researcher Leerssen sees in establishing "the intertext of a given national representation as a trope" [Beller and Leerssen 2007, 28].

Leerssen lists the range of imagological questions that a literary critic always faces: what is the tradition of this trope? to which extent is that background tradition passively or actively echoed or reinforced, varied upon, negated, mocked, or ignored? which genre conventions are at work, narrative, descriptive, humorous, propagandistic, fictional, poetic? Thus, the emphasis is placed not on fixing the content of the ethnoimage, but on the ways of its representation in a literary text, i.e., on its "textual interpretation" [Beller and Leerssen 2007, 28]. Following Leerssen, Świderska proposed to distinguish comparativist (in her terminology) imagology, linking its hermeneutic method of the interpretation with the comprehension of the "deep semantics" of cultural, national, or ethnic "alien" images manifested in the literary texts [Świderska 2013,3]. At the same time, national categories are considered by Świderska as part of research tools, but not as the main subject of research. An alternative to the extratextual sociological approach to the analysis of a literary text ("extrinsic contextualization") is the "intrinsic textual analysis" - a principle that is being developed today by literary imagology. Thus "literariness" [Wellek 1963, 293] becomes a fundamentally important aspect for a comparatist.

In the framework of imagology, the image of the Other is studied as a stereotype of the national consciousness, as a stable, powerful, generalized figurative idea of the Other, formed in a specific socio-historical environment. Beller describes a stereotype as "...a generalization about a group of people in which incidental characteristics are assigned to virtually all members of the group, regardless of actual variation among the members. Once formed, stereotypes are resistant to change on the basis of new information" [Beller and Leerssen 2007, 429]. Dyserinck's student, Fischer, proposed to replace the sociologically constituted concept of the stereotype with the specifically literary concept of the imagotype and imagotype system [Beller and Leerssen 2007,9].

It is notable, that Chinese comparatists, involved in the research of the images of the Other in the Overseas Chinese literature also develop their consideration proceeding from the stereotypes present in their mother culture regarding the other culture. The contributors to A Course of Overseas Chinese Literature suggest that there are three different 
types of manifestation of the Other as opposed to the Self in Southeast Asian Chinese literature. First, it is an image of the Other which is very close to the Self, and thus can be viewed as a collective and idealized cultural interpretation of the mother culture. The second is the image of the Other questioning reality, reflecting the distance between reality and ideals, and subverting certain conservative consciousness and prejudices being present in the mother culture. The third is the image of the Other that celebrates cultural diversity [Haiwai huawen wenxue jiaocheng 2009, 43].

Based on these principles of the methodological analysis of literary images outlined by Leerssen and his followers, both in the West and in China, we tend to research the central themes of the Overseas Chinese literature, related to the images of China. Through the cultural analysis of the Other images in the Overseas Chinese literary writings, one can reflect on the culture of the nation and grasp the contrast between two different cultures when they meet; the Other is represented through the combination and variation of different cultures in the images, bringing new meaning to the study of Overseas Chinese literature.

The protagonist in Chinese-Filipino woman writer Pei Qiong's Oil-paper Umbrella (“油纸伞” You zhi san), Li Zhenni, is half-Filipino and half-Chinese (also chushiza or Chhut-sì-á, that may be referred to as the "foreigner" in imagological terms). Her father is a Chinese intellectual and her mother is a Filipino, a university professor of comparative literature. The image of Li Zhenni in the novel is mainly created through the eyes of a pure Chinese young man Lin Wenbin. They are in love, but Lin Wenbin's mother is trying to prevent her son from marrying Li Zhenni, thinking that marrying a half-Filipino is very irrational and would affect her son's lifelong happiness. The mother refers to Li Zhenni as to fan zi (番仔, where fan imageme stands for barbarian, foreigner), which can be regarded as racial prejudice and shows the isolation between the older generations of Chinese who migrated to the Philippines and the local ethnic group. The stereotyped heteroimage of Filipinos that has been formed for a long time in the Chinese community suggests that Filipinos are a nation characterized by laziness, pursuing pleasure, and unpredictability. Haughty behavior and rejection of the Other imply the Chinese affirmation of the fine Chinese virtues (Lin Wenbin's mother reminds him of xiao or 孝 - filial piety, a central virtue in Confucian role ethics), which brings only suffering to the younger generation of Chinese. Interestingly, that Li Zhenni articulated similar age-old stereotypes that form an autoimage of the Filipino-Chinese: "My sorrow is that I am a potato, no matter how hard I am trying, no matter what I am longing for, no matter how yellow I am inside, the outside is still brown” (我的悲哀是一一自己是马铃薯, 不管怎样的努力, 不管怎样的向往, 不管内里怎样的黄了, 外面仍然是褐色的 [Haiwai huawen wenxue duben... 2009, 53]). Lin Wenbin cannot withstand the traditional Chinese virtues and protect their love, so he finally chose to stay and care about his mother. Li Zhenni had to give up what she loved and leave for the United States. The image of an oil-paper umbrella that can protect from the sun, but cannot withstand the wind and rain plays a symbolic role here. The author of the short story questions traditional behaviors still present in their mother culture. Through the rejection of the Other by the mothers, Pei Qiong is trying to underline the conflict between two cultures and a lack of critical understanding of the Self. Still, the hidden implicit narrator of the short story articulates modern national consciousness, which assumes the unacceptability of image confrontation between cultures.

It is significant that in recent years in China, in the context of globalization and intensive translation practice, the academic interest in the literature of the Chinese diaspora is noticeably increasing. This is manifested in many critical articles, in the center of which is an analysis of the transnational and universal issues, which, of course, brings the interpretation of the works of authors of Chinese origin closer to transnational, global narratives. The term of Global Chinese literature (世界华文文学 shijie huawen wenxue) was 
coined to emphasize its world-wide presence and universality of its narratives. The emerging new vector in the interpretation of the works of writers of Chinese origin marks the intention of Chinese scholars to revise the Chinese-language literature from a global point of view. Instead of geographically dividing Chinese-language literature into mainland and non-mainland parts, they view it as a worldwide construct that should be viewed on a par with literary works in English, French, and Spanish [Leung 2006, 118]. Tsu and Wang place special emphasis on the fact, that as China continues to re-establish itself as a world power in the twenty-first century, the centripetal pull of its economic presence creates a renewed cultural gravitation. That global Chinese literature can be under discussion at all bespeaks a renewed concern with the perpetuation of nation-based narrative as the only worthy narrative [Tsu and Wang 2010, 6], accompanied by a critical network of minority discourses.

Transcultural realities in today's world bring about new horizons in the imagological studies that go beyond the notions of the Self and the Other, or heteroimages and autoimages, but calls for consideration of the postnational identities. Researchers from both European and American schools [Tötösy de Zepetnek 1998; Chow 2000; Damrosch 2014], and Chinese school [Ning 2004; Cao 2000; Ang 2001; Yue 2004] agree that the processes of globalization require both a rethinking of already existing concepts and the development of new methodological paradigms in comparative studies. Leerssen also notes that "[imagology] in its method, if not subject-matter, can be postnational, transnational" [Beller and Leerssen 2007, 21]. He traces the prospects for the methodology of postnational, transnational imagology in the works of his predecessors, Carré and Guyard, whose concepts are based on the rejection of a belief in the realness of national characters. In "Imagology and the Problem of Ethnic Identity" Dyserinck also addresses this perspective in the science development as a "case in postnational thought" [Dyserinck 2003], as a direction in the study of postnational models of identity. The same approach is voiced in Shih's "Against diaspora: The Sinophone as Places of Cultural Production", offering a broad, programmatic call for a transnational approach to the study of Chinese language literature. Shih uses the term Sinophone to designate the only significant "linguistic identity" of Sinitic-language cultures and communities outside China. Unlike the unstable conception of the Chinese diaspora, the Sinophone foregrounds not the blood ties, ethnicity, and homeland of a person but the languages he or she speaks; it is an analytical and cognitive category, which is both geographically and temporarily specific [Shih 2010, 39]. Shih tends to theorize the Sinophone discourse as "inherently transnational" and argues that truly Global Chinese literature is possible only when the most powerful articulations against China-centrism are voiced.

An Overseas Chinese female writer, You You, describes her experience of living in different parts of the world (New Zealand, Australia, the UK) questioning the very Self that requires meaning: "What am I now? When returning home, people say I am aping foreigners; when staying abroad I am still feeling uncomfortable. Neither Chinese nor foreigner, neither an overseas Chinese nor myself, neither fish nor fowl!” (如今我是什 么? 回到自己的家园，人家说你假洋鬼子; 呆在外面又浑身不自在，既不是中国人， 也不是外国人; 不是华侨, 不是自己, ‘四不像'?! [Yang and You 1994, 6]). There is both the ironic reference to the Lu Xun's Story of Ah Q, from where the imageme jia yangguizi (假洋鬼子, “imitation foreign devil”, a Chinese who apes foreigners) comes from and despair of a person, not having roots, questioning her belonging to China. Transnational identity is also a distinctive feature of Yan Geling's, Hong Ying's, Zhang Rong's, Zhang Ping's, Min Anqi's and Ha Jin's writings, to name a few. The transcultural imagery of their writings, which hardly shows the traces of Overseas Chinese and pursues worldwide literary style, is not limited to the problem of national and cultural identity.

Wan Zhi (pen name of Chen Maiping) is a Chinese-Swedish writer and poet, famous for his translations of many Chinese writers such as Mo Yan, Yu Hua, Su Tong, Han 
Shaogong, and Wang Anyi into Swedish and English, and is generally recognized as a respected contributor to the spread of Chinese literature in the West. His writings reveal universal themes of Self-searching and usage of the psychoanalysis technique to depict the complex emotional connections between people. His short story "The Woman in a Trench Coat” (“穿风衣的女人” chuan fengyi de nuren) employs Wan Zhi's experiments with a form of dramatic dialogue and a stream of consciousness narrative technique, which in many ways resembles the style of Gao Xingjian, the most recognized overseas writer of Chinese descent according to the 2000 Nobel Prize committee. The narrator represented through the several Selves questions and argues who is and who is waiting for the woman wearing a trench coat on the bus-stop, seen by him from a coffee-shop window. The story does not mention a place, country, cultural realities, nor does it represent any stereotypical images. Instead, it provides an in-depth psychological analysis of a character as an "arbitrary" or "post-" identity. The location of "in-betweenness" is the key in grasping the author's intention not to prescribe any national, ethnic, or cultural identity to a person, but to be wholly involved in his psychological portrait. In a similar vein, there are a lot of intertextual references to the world classics, as the narrator mentions Lermontov's A Hero of Our Time, Tolstoy, Dumas' The Count of Monte Cristo, reflects on the images of Sherlock Holmes, and Pavel and Tonya from the How the Steel was Tempered. The western type of narration and a postmodern hypertextuality seems to remote this short story from a dominant image of the Chinese nation. Still, the story possesses a very significant, in imagological terms, implication that the narrator of the story is Chinese - he supposes that this woman may have married a laowai (“嫁给老外了” [Haiwai huawen wenxue duben... 2009, 285]), which is the Chinese slang word for "foreigner" instead of formal and polite waiguoren (外国人). But it is important to emphasize that the poetic and semantic load of the narration makes this detail unintentional. The author introduces a way of an overseas Chinese representation different from the discursive poetics of the Overseas Chinese literature. That is the representation of a transcultural image, not limited by the notions of national and cultural identity.

In fact, after the 1990s, the research community has been facing a tendency, that Overseas Chinese literature does not necessarily mirror a "Chinese consciousness". The literary and aesthetic aspects of the literature become the cornerstone of the studies that view Chineseness as the aesthetic value. The ultimate goal of such studies thus should be considering the literariness and aesthetics of Overseas Chinese writings and describing its unique literary paradigm and poetics. As Rao Pengzi and Yang Kuanghan have correctly noted, that literature as a unique aesthetic activity praises three basic principles of truth, goodness, and beauty (真善美 zhen shan mei) [Haiwai huawen wenxue jiaocheng 2009, 27], and these three are what matters when studying any literary phenomenon. The new approach features the analysis of the peculiarities of the aesthetic representation of national and cultural images and the consideration of an image as an important literary device. The study of literary representations makes it possible to identify textual strategies for embodying the images of the many-sided world in the Overseas Chinese literature, which is global, both in terms of its geography and properties.

\section{REFERENCES}

Ang I. (2001), On not speaking Chinese: living between Asia and West, Psychology Press, Hove.

Beller M. and Leerssen J. T. (2007), The cultural construction and literary representation of national characters: a critical survey, Rodopi, Amsterdam.

Bernheimer C. (1995), "Introduction: The anxieties of comparison", in Bernheimer C. (ed.), Comparative literature in the age of multiculturalism, The John Hopkins University Press, Baltimore, MD, pp. 1-20.

The World of the Orient, 2021, № 1 
Cao S. (2000), "Chinese school of comparative literature: the theoretical fundamentals and its system of methodology", Comparative Literature: East \& West, Vol. 1, pp. 44-70.

Chen X. (2002), Occidentalism: a theory of counter-discourse in post-Mao China, Rowman \& Littlefield, Lanham, MD.

Chow R. (2000), "Introduction: on Chineseness as a theoretical problem", in Chow R. (ed.), Modern Chinese literary and cultural studies in the age of theory, Duke UP, Durham, NC, pp. 1-25. Damrosch D. (2014), World literature in theory, Wiley-Blackwell, New York, NY.

Dyserinck H. (2003), "Imagology and the problem of ethnic identity", Intercultural Studies, Vol. 1, pp. 285-294.

Fusco S. (2006), "The ironies of comparison: comparative literature and the re-production of cultural difference between East and West", TRANS- [En ligne], No. 2, available at: https://journals.openedition.org/trans/167 (accessed January 2, 2021).

Hutcheon L. (1996), "Comparative literature's anxiogenic state", Canadian review of comparative literature, Vol. 23, No. 1, pp. 35-41.

Leung L. (2006), "Overseas Chinese literature: A proposal for clarification", in Ng M. N. and Holden P. (eds), Reading Chinese transnationalisms: society, literature, film, Hong Kong University Press, Hong Kong, pp. 117-128.

Ning W. (2004), "Comparative literature and globalism: a Chinese cultural and literary strategy", Comparative Literature Studies, Vol. 41, No. 4, pp. 584-602.

Ong A. and Nonini D. (1997), Ungrounded empires: the cultural politics of modern Chinese transnationalism, Routledge, New York, NY.

Palumbo-Liu D. (1992), "The utopias of discourse: on the impossibility of Chinese comparative literature", Chinese Literature: Essays, Articles, Reviews (CLEAR), Vol. 14, pp. 165-176.

Rao P. (2011), "The overseas Chinese language literature in a global context", Revue de littérature comparée, Vol. 1, No. 337, pp. 106-112.

Said E. W. (2003), Orientalism: Western conceptions of the Orient, Penguin Classics, London.

Shih S.-m. (2010), "Against diaspora: The Sinophone as places of cultural production", in Tsu J. and Wang D. (eds), Global Chinese literature: critical essays, Brill Press, Leiden, pp. 29-48.

Shu Y. (2005), "Globalization and 'Asian values': teaching and theorizing Asian American literature", College Literature, Vol. 32, No. 1, pp. 86-102.

Świderska M. (2013), "Comparativist imagology and the phenomenon of strangeness", CLCWeb: Comparative Literature and Culture, Vol. 15, Issue 7, available at: https://docs.lib.purdue.edu/clcweb/vol15/iss7/13/ (accessed January 2, 2021).

Tötösy de Zepetnek S. (1998), Comparative Literature: theory, method, application, Rodopi, Amsterdam.

Tsu J. and Wang D. (2010), "Introduction: global Chinese literature", in Tsu J. and Wang D. (eds), Global Chinese literature: critical essays, Brill Press, Leiden, pp. 1-13.

Wellek R. (1963), Concepts of Criticism, Yale University Press, New Haven, CT.

Wu D. Y.-h. (1991), "The construction of Chinese and non-Chinese identities", The living tree: the changing meaning of being Chinese today, Vol. 120, No. 2, pp. 159-179.

Zhang L. (1994), "Out of the cultural ghetto: Theory, politics, and the study of Chinese literature", Southeast Asian Journal of Social Science, Vol. 22, pp. 21-41.

Zhang Y. (1998), "Introduction: engaging Chinese comparative literature and cultural studies", in Zhang Y. (ed.), China in a polycentric world: essays in Chinese comparative literature, Stanford University Press, Redwood, CA, pp. 1-18.

Cheung K. et al. (2018), "Xin shiji de meiguo ji haiwai huayi wenxue", Jiangnan Magazine, No. 2, pp. 146-159. (In Chinese).

Gong Zhong (2000), Shijiehuawen wenxue gailun, Renmin wenxue chubanshe, Beijing. (In Chinese).

Haiwai huawen wenxue duben. Duan pian xiaoshuo juan (2009), Wu Y. (ed), Jinan daxue chubanshe, Guangzhou. (In Chinese).

Haiwai huawen wenxue jiaocheng (2009), Rao P. and Yang K. (eds), Jinan University Press, Guangzhou. (In Chinese).

Lai Bojiang (1993), Haiwan huawenwenxue gaiguan, Haixia wenyi chubanshe, Fuzhou. (In Chinese).

Pan Yadun (1996), Haiwanhuawen wenxue xianzhuang, Renmin wenxue chubanshe, Beijing. (In Chinese). 
Rao Bozi (2004), Shijiehuawen wenxue de xin shiye, Zhongguo shehui kexue chubanshe, Beijing. (In Chinese).

Yang L. and You Y. (1994), Renjing Guihua, Zhongyang bianyì chuban she, Beijing. (In Chinese).

Yue Daiyun (2004), Yue Daiyun jiaoshou haiwai jiangyan lu, Beijing daxue chubanshe, Beijing. (In Chinese).

\section{T. В. Вечоринська, О. С. Воробей}

\section{Література китайської діаспори: імагологічний аспект}

Література китайської діаспори - це термін, що позначає літературні твори, написані китайською мовою поза теренами Китаю. Вкорінена у грунті китайської культури, література китайської діаспори постає як унікальне літературне явище, поширене у всьому світі, що створюється в осередку іноземних культур. Письменники китайського походження за кордоном пишуть в умовах чужого оточення, їхні праці вирізняються різноманіттям літературних репрезентацій зустрічі, зіткнення та злиття різних культур. У статті пропонується імагологічний підхід до дослідження літератури китайської діаспори, який може відповісти на питання про те, як китайська діаспора визначає себе для побудови власної ідентичності на відміну від усього іншого, що вони вважають некитайським. Із застосуванням методів західної та китайської шкіл порівняльного літературознавства та їхньої відповідної інтерпретації світових літературних процесів стаття окреслює історичні та теоретичні засади літературної імагології й розкриває сутність таких суперечливих категорій, як “китайськість", “китайська свідомість". У статті подається імагологічна інтерпретація взаємодії "Я” та "Іншого" в оповіданні китайсько-філіппінської письменниці Пей Цюн “Паперова парасолька”. Пропонується розглядати інтертекст національної репрезентації як троп і відтак вивчати семантику та поетику транснаціональних репрезентацій. Проведений аналіз сучасних критичних підходів до літератури китайської діаспори показує, що вектор критичного осмислення цього літературного явища поступово відходить від етнічної парадигми до транснаціональної, транскультурної інтерпретації зв'язку людини з материнською культурою. У статті досліджується, у який спосіб транскультурні іміджі вибудовуються в уявному літературному просторі, та як вони репрезентуються в літературному тексті. Особливий наголос робиться на методах літературної імагології, що враховує внутрішні текстуальні особливості понад зовнішніми етноцентричними концепціями. Показано, що транскультурні образи, втілені в оповіданні китайсько-шведського письменника Ваня Чжи “Жінка у плащі”, не можна звузити суто до контекстуалізації діади “Я та Інший”, що розглядається як сутність глибокого культурного значення в галузі досліджень літератури китайської діаспори.

Ключові слова: Я, Інше, літературна імагологія, література китайської діаспори, транскультурна ідентичність 